\title{
Does herpes zoster predispose to giant cell arteritis: a geo-epidemiologic study
}

This article was published in the following Dove Press journal:

Clinical Ophthalmology

\author{
Edsel B. Ing ${ }^{1,2}$ \\ Royce Ing ${ }^{2}$ \\ Xinyang Liu $^{3}$ \\ Angela Zhang' \\ Nurhan Torun ${ }^{4}$ \\ Michael Sey ${ }^{5}$ \\ Christian Pagnoux ${ }^{6}$ \\ 'Ophthalmology and Vision Sciences, \\ University of Toronto, Toronto, \\ ON, ${ }^{2}$ Toronto Eyelid Strabismus \& \\ Orbit Surgery Clinic, Toronto, ON, \\ Canada; ${ }^{3}$ Department of Medicine, \\ Internal Medicine, Fudan University, \\ Shanghai, China; ${ }^{4}$ Ophthalmology, \\ Harvard Medical School, Boston, \\ MA, USA; ${ }^{5}$ Department of Medicine, \\ Western University Schulich School \\ of Medicine, London, ON, ${ }^{6}$ Vasculitis \\ Clinic, Rheumatology, Mount Sinai \\ Hospital, Toronto, ON, Canada
}

Correspondence: Edsel B. Ing Toronto Eyelid Strabismus \& Orbit Surgery Clinic, Michael Garron Hospital, 650 Sammon Ave, K Wing 306, Toronto, ON, M4C 5M5, Canada

Tel + I 4164657900

Fax + I 4164652035

Email edinglidstrab@gmail.com
Purpose: Giant cell arteritis (GCA) is the most common systemic vasculitis in the elderly and can cause irreversible blindness and aortitis. Varicella zoster (VZ), which is potentially preventable by vaccination, has been proposed as a possible immune trigger for GCA, but this is controversial. The incidence of GCA varies widely by country. If $\mathrm{VZ}$ virus contributes to the immunopathogenesis of GCA we hypothesized that nations with increased incidence of GCA would also have increased incidence of herpes zoster (HZ). We conducted an ecologic analysis to determine the relationship between the incidence of HZ and GCA in different countries.

Methods: A literature search for the incidence rates (IRs) of GCA and HZ from different countries was conducted. Correlation and linear regression was performed comparing the disease IR of each country for subjects 50 years of age or older.

Results: We found the IR for GCA and HZ from 14 countries. Comparing the IRs for GCA and $\mathrm{HZ}$ in 50-year-olds, the Pearson product-moment correlation $(r)$ was -0.51 , with linear regression coefficient $(\beta)-2.92(95 \% \mathrm{CI}-5.41,-0.43 ; p=0.025)$ using robust standard errors. Comparing the IRs for GCA and HZ in 70-year-olds, $r$ was -0.40 , with $\beta-1.78$, which was not statistically significant $(95 \% \mathrm{CI}-4.10,0.53 ; p=0.12)$.

Conclusion: Although this geo-epidemiologic study has potential for aggregation and selection biases, there was no positive biologic gradient between the incidence of clinically evident $\mathrm{HZ}$ and GCA.

Keywords: epidemiology, shingles, temporal arteritis, immunopathogenesis

\section{Introduction}

Giant cell arteritis (GCA) is the most common systemic vasculitis in the elderly and can cause irreversible blindness, myocardial infarction, aortic aneurysm, stroke and rarely death. ${ }^{1}$ The incidence of GCA is projected to increase as our population ages, with predicted cost of $\$ 76$ billion in the United States alone, by the year $2050 .^{2}$

Gilden et al and Nagel et al found varicella zoster virus (VZV) in the temporal arteries of $73 \%$ of patients with biopsy-proven GCA and propose VZV as a possible trigger in the immunopathogenesis of GCA. ${ }^{3,4}$ Although this potential role of VZV in the development of GCA has not been substantiated by other investigators, and remains controversial, Gilden suggested adjunctive antivirals be considered in the treatment of GCA. ${ }^{5}$

The incidence rate (IR) of GCA varies widely by country, being the highest in northern Europe and lowest in Asia. ${ }^{2,6}$ We hypothesized that if VZV contributed to GCA, the GCA IRs per 100,000 subjects, 50 years of age or older ( IR $\left._{\mathrm{GCA}}\right)$ per country should correlate with the local herpes zoster IRs $\left(\operatorname{IR}_{\mathrm{HZ}}\right)$. To test this hypothesis, we performed a regression analysis using the published $\mathrm{IR}_{\mathrm{GCA}}$ and $\mathrm{IR}_{\mathrm{HZ}}$ from different countries. 


\section{Methods}

The $I_{\mathrm{GCA}}$ was searched for on PubMed, Embase, and Google Scholar from inception to July 1, 2017 using the search terms: incidence, epidemiology, country, temporal arteritis and GCA. The same search was repeated using herpes zoster and shingles in place of the arteritis terms.

The country specific IRs for subjects 50 years of age and older were recorded per 100,000 population for GCA, and per 1,000 person-years for HZ. If IRs were provided for multiple years, the results were averaged (Table 1).

The $\mathrm{IR}_{\mathrm{GCA}}$ in Japan was calculated using Koboyashi's reported prevalence rate of 1.47 per 100,000 in subjects aged 50 years or older, with average age of onset of 71.5 years. $^{7}$ Lifespan is thought not to be affected by GCA unless the patient has aortic aneurysm or dissection. ${ }^{8}$ The average life expectancy in Japan is 83.3 years. ${ }^{9}$ As GCA is a rare disease and recurrent, the IR was estimated as the prevalence rate/ duration of disease $=1.3$ per million subjects 50 years or older.

Since the peak onset of GCA is in the 8 th decade, ${ }^{10}$ we also examined the IR of $\mathrm{HZ}$ in 70 year-olds. If the age brackets straddled our chosen age cut-offs, the IR values from the two adjacent brackets were averaged.

Only countries/regions that had IRs available for both GCA and HZ were used for analysis. Paired $t$-test was used to examine the time difference in year of publication between the GCA and HZ studies for each country. There was inadequate information in the GCA articles to consistently calculate the within-study standard errors needed for metaregression. Pearson product-moment correlation coefficients, and linear regression with and without robust standard errors was performed. White's test was used to test for heteroscedasticity. All statistical tests were conducted with Stata 14.2 (StataCorp LP, College Station, TX, USA), and a two-sided $p<0.05$ was considered statistically significant.

\section{Results}

The IRs for both GCA and HZ were available for 14 countries (Table 1), and plotted on Figure 1. With the exception of Olmsted County and the United Kingdom, the availability of $\mathrm{IR}_{\mathrm{GCA}}$ and $\mathrm{IR}_{\mathrm{HZ}}$ from the same time frame and corresponding geographic region was limited. Eight of the 14 countries $(57 \%)$ in Table 1 were overlapping in the time frame of the corresponding GCA and $\mathrm{HZ}$ studies. On paired $t$-test, the GCA studies were published on average 4.5 years before the $\mathrm{HZ}$ studies $(p=0.09)$. A published $\mathrm{IR}_{\mathrm{GCA}}$ for Iceland was available. The $\mathrm{IR}_{\mathrm{HZ}}$ for Iceland was only available for the 60 -year age group only $(4.7$ per 1,000$)$, but not the 50 -yearold or 70-year-old age groups, and as such was not used.

Pearson product-moment correlation coefficient $(r)$ comparing $\mathrm{IR}_{\mathrm{GCA}}$ with: $\mathrm{IR}_{\mathrm{HZ}}$ in 50 year-olds was -0.51 ( $\left.p=0.07\right)$, and $\mathrm{IR}_{\mathrm{HZ}}$ in 70 -year-olds was $-0.40(p=0.16)$. Linear regression with robust standard errors showed a regression coefficient $(\beta)-2.92(95 \% \mathrm{CI}-5.41,-0.43 ; p=0.025)$ between the $\mathrm{IR}_{\mathrm{GCA}} \geq 50$-year-olds, and the $\mathrm{IR}_{\mathrm{HZ}}$ in 50 -year-olds. For the $\mathrm{IR}_{\mathrm{Hz}}$ in 70-year-olds, no statistically significant linear dependence of the mean $\mathrm{IR}_{\mathrm{GCA}}$ on $\mathrm{IR}_{\mathrm{HZ}}$ was detected ( $\beta=-1.78,95 \% \mathrm{CI}-4.10,0.53 ; p=0.12)$. White's test did not suggest heteroscedasticity (Table 2 ).

Table I Incidence rates of giant cell arteritis and herpes zoster per country

\begin{tabular}{|c|c|c|c|c|c|c|}
\hline Country & $\begin{array}{l}\text { GCA study: year published } \\
\text { (study period)/region }\end{array}$ & $\mathbf{I R}_{\mathrm{GCA}}$ & HZ study: year/region & $\mathbf{I R}_{\mathrm{HZ} 50}$ & $\mathbf{I R}_{\mathrm{HZ70}}$ & $\begin{array}{l}\text { Time } \\
\text { overlap }\end{array}$ \\
\hline Norway, $B+C^{37}$ & $2014(2006-2012) /$ South & 21 & 2016 (2008-20I2)/National ${ }^{38}$ & 2.8 & 7.0 & Yes \\
\hline Finland, $\mathrm{B}+\mathrm{C}^{39}$ & 1992 (1984-1988)/West Nyland & 26.2 & $2010(2000-2006) /$ Tuusula, Kangasala, Salo ${ }^{40}$ & 2.5 & 6.5 & No \\
\hline Sweden, $B^{41}$ & $2015(1997-2010) / S k a n e$ & 14.1 & $2013(2006-2010) /$ National $^{42}$ & 2.5 & 8.0 & Yes \\
\hline United Kingdom, $\mathrm{B}+\mathrm{C}^{43}$ & $2006(1990-200 \mid) /$ National & 22 & $2003(|99|-2000) /$ National ${ }^{44}$ & 4.0 & 9.3 & Yes \\
\hline USA, $C^{45}$ & 2015 (2000-2009)/OImsted Cty & 19.8 & 2016 (1945-2007)/Olmsted City ${ }^{46}$ & 4.5 & 8.4 & Yes \\
\hline Spain, $B^{47}$ & 2007 (I98I-2005)/Lugo & 10.13 & $2013(2007-2010) /$ Valencian Community ${ }^{48}$ & 4.8 & 9.8 & No \\
\hline New Zealand, ${ }^{49}$ & 2011 (1996-2005)/Otago & 12.73 & 2014 (2009-2013)/Lower Hutt ${ }^{50}$ & 6.1 & 7.3 & No \\
\hline Israel, $B+C^{51}$ & 2007 (I 980-2004)/Jerusalem & 11.3 & $2013(2006-2010) /$ Tel Aviv ${ }^{52}$ & 5.8 & 11.8 & No \\
\hline Canada, $\mathrm{B}^{53}$ & 2007 (I998-2003)/Saskatoon & 9.4 & 2011 (1992-2010)/Ontario ${ }^{54}$ & 3.7 & 7.4 & Yes \\
\hline France, $B+C^{55}$ & 1982 (1970-1979)/Loire-Atlantique & 9.4 & $2010(2005-2007) /$ National $^{56}$ & 4.2 & 8.7 & No \\
\hline Italy, $B+C^{57}$ & 2017 (1986-2012)/Reggio Emilia & 5.8 & $2010(2003-2005) /$ Nationa $^{58}$ & 3.6 & 7.7 & Yes \\
\hline Australia, $\mathrm{B}^{59}$ & $2013(1992-2011) /$ Adelaide & 3.2 & $2008(1998-2006) /$ National $^{60}$ & 6.5 & 11.5 & Yes \\
\hline Germany, $C^{61}$ & 2005 (1998-2002)/Schlewig-Holstein & 3.3 & 201 I (2007-2008)/National ${ }^{62}$ & 6.2 & 11.3 & No \\
\hline Japan, $\mathrm{Cal}^{7}$ & 2003 (1998)/National & 0.13 & 2009 (I 997-2006)/Miyazaki63 & 3.9 & 7.4 & Yes \\
\hline
\end{tabular}

Notes: B, biopsy proven; C, clinical criteria for diagnosis; Cal, calculated from published prevalence rate; Time overlap, the incidence rates for GCA and $\mathrm{HZ}$ were from the same time period.

Abbreviations: GCA, giant cell arteritis; IR, incidence rate; $\mathbb{R}_{G C A}$, giant cell arteritis incidence rates per 100,000 subjects, 50 years of age or older; $H Z$, herpes zoster; $I_{\mathrm{HZs0}}$, herpes zoster incidence rates in 50-year-old subjects per I,000 person years; $I R_{H z 70}$, herpes zoster incidence rates in 70 -year-old subjects per $I, 000$ person years. 


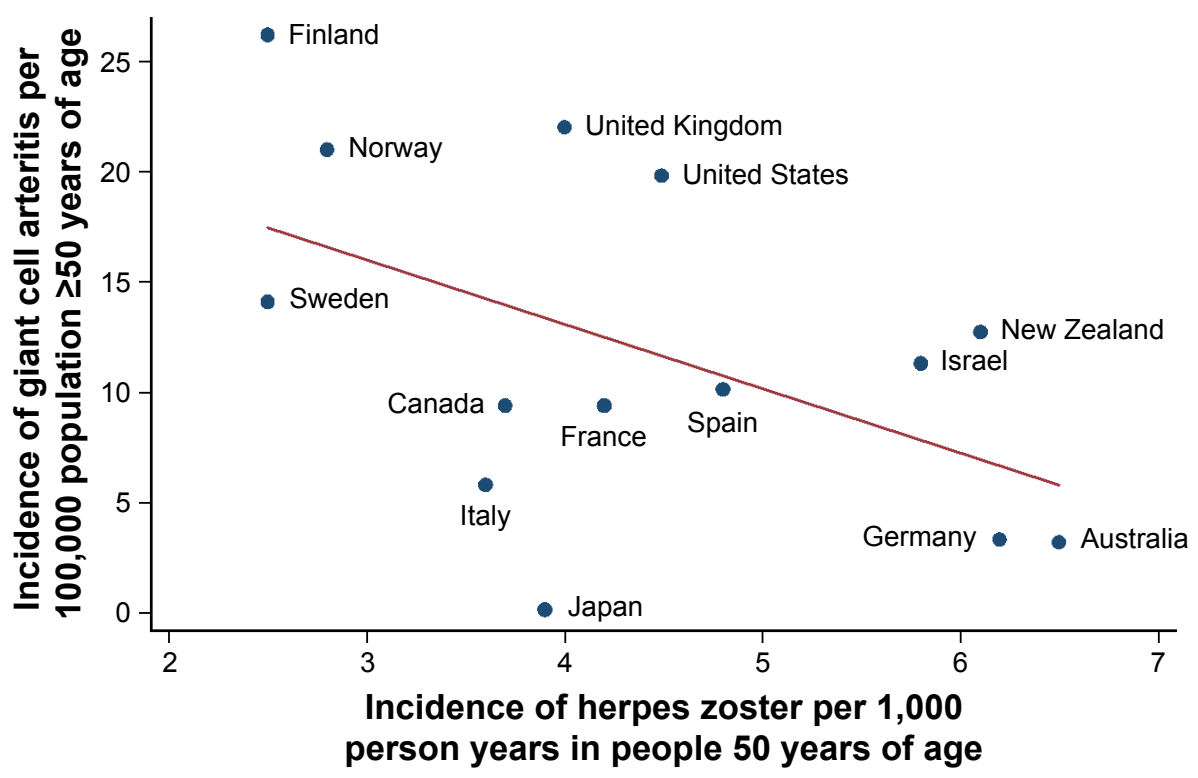

Figure I Incidence of giant cell arteritis versus incidence of herpes zoster per country.

Notes: Each dot represents a country's intersecting incidence rates for giant cell arteritis in subjects 50 years or older, and herpes zoster in 50 year-old subjects. The negative sloping red line is the line of best linear fit using the least squares method.

This ecologic study does not support a positive biologic gradient between the $\mathrm{IR}_{\mathrm{HZ}}$ and $\mathrm{IR}_{\mathrm{GCA}}$. Subgroup regression analyses of the per country $\mathrm{IR}_{\mathrm{GCA}}$ and $\mathrm{IR}_{\mathrm{HZ}}$, with and without overlapping timeframes were not statistically significant and did not show a positive regression coefficient.

\section{Discussion}

Infections can predispose to systemic vasculitis by mechanisms such as molecular mimicry, epitope spreading, immune response to subdominant epitopes normally hidden from T-cell recognition, or bystander activation. ${ }^{11}$ If there is a causal relationship between $\mathrm{HZ}$ and GCA it is important to define since $\mathrm{HZ}$ can be potentially prevented with the shingles vaccine, and because the treatment of GCA might benefit from adjunctive antivirals.

VZV and GCA have some overlapping features. Dendritic cells are thought to play a central role in VZV infection and the immunopathogenesis of GCA. ${ }^{12-14} \mathrm{HZ}$ ophthalmicus or multifocal VZV vasculopathy with temporal artery infection may mimic the presentation of GCA. Varicella zoster vasculopathy and GCA can both cause optic neuropathy, cranial nerve palsy, and stroke.

Temporal artery biopsy studies have shown conflicting results on the association of VZV and GCA. Gilden et al and Nagel et al suggested that VZV triggers the immunopathology of GCA, and found increase of $74 \% \mathrm{VZV}$ in temporal artery biopsy specimens from patients with GCA. ${ }^{3-5,15}$ However, with the exception of Mitchell and Font, ${ }^{16}$ other investigators have not found substantial VZV in the arterial specimens of biopsy-proven GCA or clinically diagnosed GCA. ${ }^{17-22}$ False positive immunohistochemistry from antibody crossreactivity to shared epitopes between VZV proteins and arterial smooth muscle elements suggest caution when interpreting pathology findings. ${ }^{23}$ Gilden and Nagel acknowledge

Table 2 Correlation and linear regression of the incidence rates of giant cell arteritis versus herpes zoster

\begin{tabular}{lllllll}
\hline $\begin{array}{l}\text { Zoster incidence rate } \\
\text { age groups }\end{array}$ & $\begin{array}{l}\text { Number of } \\
\text { countries }\end{array}$ & $\begin{array}{l}\text { Correlation } \\
\text { coefficient }\end{array}$ & $\begin{array}{l}\text { Regression } \\
\text { coefficient }\end{array}$ & $p$-value, $\mathbf{R}^{2}$ & $\begin{array}{l}p \text {-value with } \\
\text { robust SE }\end{array}$ & $\begin{array}{l}p \text {-value for } \\
\text { white's test }\end{array}$ \\
\hline 50-year-olds, all countries & 14 & $-0.5 \mathrm{I}$ & -2.92 & $p=0.07, R^{2}=0.26$ & $p=0.025$ & $p=0.28$ \\
70 -year-olds, all countries & 14 & -0.40 & -1.78 & $p=0.16, R^{2}=0.16$ & $p=0.12$ & $p=0.42$ \\
50 -year-olds, time overlap & 8 & -0.38 & -2.66 & $p=0.35, R^{2}=0.14$ & $p=0.06$ & $p=0.12$ \\
70 -year-olds, time overlap & 8 & -0.15 & -0.88 & $p=0.72, R^{2}=0.02$ & $p=0.69$ & $p=0.88$ \\
50 -year-olds, no overlap & 6 & -0.80 & -4.24 & $p=0.06, R^{2}=0.63$ & $p=0.05$ & $p=0.93$ \\
70 -year-olds, no overlap & 6 & -0.74 & -2.63 & $p=0.09, R^{2}=0.54$ & $p=0.14$ & $p=0.09$ \\
\hline
\end{tabular}

Notes: Correlation coefficient, Pearson product-moment correlation coefficient ( $r$ ); regression coefficient, linear regression coefficient; time overlap, the incidence rates for $\mathrm{GCA}$ and $\mathrm{HZ}$ were from the same time period; no overlap, the incidence rates for $\mathrm{GCA}$ and $\mathrm{HZ}$ were from different time periods.

Abbreviations: GCA, giant cell arteritis; $\mathrm{HZ}$, herpes zoster; SE, standard error. 
that "the presence of VZV in about $20 \%$ of temporal artery biopsies from non-GCA post-mortem controls also suggests that VZV alone is not sufficient to produce disease". 5

A population-based cohort study did not find an increased risk of $\mathrm{HZ}$ in patients with GCA compared to non-GCA subjects, even during the first 6 months after glucocorticoid initiation, when patients are on the highest doses. ${ }^{24}$ A large nested case control study determined that HZ had a modest incidence rate ratio of 1.17 in association with incident GCA. ${ }^{25}$ A review of two large administrative databases found a two-fold increased risk of GCA with complicated HZ. ${ }^{26}$

Our ecologic study did not show a positive biologic gradient between the $\mathrm{IR}_{\mathrm{HZ}}$ and $\mathrm{IR}_{\mathrm{GCA}}$. Limitations of this study include possible ecologic fallacy, time, location and/or selection biases, the limited availability of $\mathrm{IR}_{\mathrm{GCA}}$ and $\mathrm{IR}_{\mathrm{HZ}}$, and variable trends in IR. By and large the $\mathrm{IR}_{\mathrm{HZ}}$ are increasing. ${ }^{27}$ Zoster sine herpete and asymptomatic VZV infection may have affected our analysis. The $\mathrm{IR}_{\mathrm{GCA}}$ may be increasing, ${ }^{2}$ decreasing, ${ }^{6}$ or cyclical. ${ }^{28}$ Furthermore, the $\mathrm{IR}_{\mathrm{GCA}}$ are higher when cases of clinically diagnosed GCA are included with biopsy-proven GCA. It is unlikely that the $\mathrm{IR}_{\mathrm{HZ}}$ in Table 1 were significantly affected by zoster vaccination. The Oka/Merck zoster vaccine decreases the risk of shingles by only $51 \%,{ }^{29}$ and was approved for use in the United States and European Union in 2006, ${ }^{30,31}$ and in Canada in 2008. ${ }^{32}$ The Olmsted county HZ study published in 2016 reviewed two sets of patients, the latest of which were from 1980 to 2007. In the United States a 5\% random sample of Medicare seniors were first offered zoster vaccine in 2007 , and uptake was low at $3.9 \% .^{33}$ The first two European countries to recommend nation-wide zoster vaccination for seniors 65 to 74 years of age were the United Kingdom and France in 2013. ${ }^{34}$ The Australian and Ontario, Canada immunization programs for seniors began in $2016.35,36$

\section{Conclusion}

The discordant IRs for HZ and GCA question the biologic plausibility of clinically overt $\mathrm{HZ}$ as the sole immunopathogenic trigger for GCA. Geo-epidemiology may help elucidate the relationship between VZV and GCA, but more widely available, accurate and updated IRs from different countries are required.

\section{Disclosure}

The authors report no conflicts of interest in this work.

\section{References}

1. Lie J. Aortic and extracranial large vessel giant cell arteritis: a review of 72 cases with histopathologic documentation. Semin Arthritis Rheum. 1995;24(6):422-431.

2. De Smit E, Palmer AJ, Hewitt AW. Projected worldwide disease burden from giant cell arteritis by 2050. J Rheumatol. 2015;42(1):119-125.
3. Gilden D, White T, Khmeleva N, et al. Prevalence and distribution of VZV in temporal arteries of patients with giant cell arteritis. Neurology. 2015;84(19):1948-1955.

4. Nagel MA, White T, Khmeleva N, et al. Analysis of varicella-zoster virus in temporal arteries biopsy positive and negative for giant cell arteritis. JAMA Neurol. 2015;72(11):1281-1287.

5. Gilden D, Nagel MA. Varicella zoster virus and giant cell arteritis. Curr Opin Infect Dis. 2016;29(3):275-279.

6. Mahr A, Aouba A, Richebé P, Gonzalez-Chiappe S. Épidémiologie et histoire naturelle de l'artérite à cellules géantes (Horton). [Epidemiology and natural history of giant cell arteritis]. Rev Med Interne. 2017;38(10): 663-669. French.

7. Kobayashi S, Yano T, Matsumoto Y, et al. Clinical and epidemiologic analysis of giant cell (temporal) arteritis from a nationwide survey in 1998 in Japan: the first government-supported nationwide survey. Arthritis Rheum. 2003;49(4):594-598.

8. Kermani TA, Kenneth J, Warrington KJ, et al. Large-vessel involvement in giant cell arteritis: a population-based cohort study of the incidencetrends and prognosis. Ann Rheum Dis. 2013;72(12):1989-1994.

9. United Nations. World population prospects: The 2015 revision, volume I, comprehensive tables. New York 2015. ST/ESA/SER.A/379. Available from: https://esa.un.org/unpd/wpp/publications/Files/ WPP2015_Volume-I_Comprehensive-Tables.pdf. Accessed August 01, 2017.

10. Gonzalez-Gay MA, Vazquez-Rodriguez TR, Lopez-Diaz MJ, MirandaFilloy JA, Gonzalez-Juanatey C, Martin J, Llorca J. Epidemiology of giant cell arteritis and polymyalgia rheumatica. Arthritis Rheum. 2009;61(10):1454-1461.

11. Moiseev S, Novikov P, Smitienko I, Shchegoleva E. Giant cell arteritis, infections and biologics. Ann Rheum Dis. 2017;76(9):e29.

12. Ciccia F, Rizzo A, Ferrante A, et al. New insights into the pathogenesis of giant cell arteritis. Autoimmun Rev. 2017;16(7):675-683.

13. Samson M, Corbera-Bellalta M, Audia S, Planas-Rigol E, Martin L, Cid MC, Bonnotte B. Recent advances in our understanding of giant cell arteritis pathogenesis. Autoimmun Rev. 2017;16(8):833-844.

14. Schönrich G, Raftery MJ. Dendritic cells as Achilles' heel and Trojan horse during varicella zoster virus infection. Front Microbiol. 2015;6:417.

15. Gilden D, White T, Khmeleva N, Katz BJ, Nagel MA. Blinded search for varicella zoster virus in giant cell arteritis (GCA)-positive and GCA-negative temporal arteries. J Neurol Sci. 2016;364:141-143.

16. Mitchell BM, Font RL. Detection of varicella zoster virus DNA in some patients with giant cell arteritis. Invest Opthalmol Vis Sci. 2001; 42(11):2572-2577.

17. Muratore F, Croci S, Tamagnini I, et al. No detection of varicella-zoster virus in temporal arteries of patients with giant cell arteritis. Semin Arthritis Rheum. 2017;47(2):235-240.

18. Kennedy PG, Grinfeld E, Esiri MM. Absence of detection of varicellazoster virus DNA in temporal artery biopsies obtained from patients with giant cell arteritis. J Neurol Sci. 2003;215(1-2):27-29.

19. Helweg-Larsen J, Tarp B, Obel N, Baslund B. No evidence of parvovirus B19, chlamydia pneumoniae or human herpes virus infection in temporal artery biopsies in patients with giant cell arteritis. Rheumatology (Oxford). 2002;41(4):445-449.

20. Rodriguez-Pla A, Bosch-Gil JA, Echevarria-Mayo JE, et al. No detection of parvovirus B19 or herpesvirus DNA in giant cell arteritis. J Clin Virol. 2004;31(1):11-15.

21. Álvarez-Lafuente R, Fernández-Gutiérrez B, Jover JA, et al. Human parvovirus B19, varicella zoster virus, and human herpes virus 6 in temporal artery biopsy specimens of patients with giant cell arteritis: analysis with quantitative real time polymerase chain reaction. Ann Rheum Dis. 2005;64(5):780-782.

22. Nordborg C, Nordborg E, Petursdottir V, LaGuardia J, Mahalingam R, Wellish M, Gilden DH. Search for varicella zoster virus in giant cell arteritis. Ann Neurol. 1998;44(3):413-414.

23. Pisapia DJ, Lavi E. VZV, temporal arteritis, and clinical practice: False positive immunohistochemical detection due to antibody crossreactivity. Exp Mol Pathol. 2016;100(1):114-115. 
24. Schäfer VS, Kermani TA, Crowson CS, et al. Incidence of herpes zoster in patients with giant cell arteritis: a population-based cohort study. Rheumatology (Oxford). 2010;49(11):2104-2108.

25. Rhee RL, Grayson PC, Merkel PA, Tomasson G. Infections and the risk of incident giant cell arteritis: a population-based, case-control study. Ann Rheum Dis. 2017;76(6):1031-1035.

26. England BR, Mikuls TR, Xie F, Yang S, Chen L, Curtis J. Herpes zoster and the risk of incident giant cell arteritis. Arthritis Rheumatol. 2017;69(12):2351-2358.

27. Kawai K, Gebremeskel G, Acosta CJ. Systematic review of incidence and complications of herpes zoster: towards a global perspective. BMJ Open. 2014;4(6):e004833.

28. Wing S, Rider LG, Johnson JR, Miller FW, Matteson EL, Crowson CS, Gabriel SE. Do solar cycles influence giant cell arteritis and rheumatoid arthritis incidence? BMJ Open. 2015;15(5): 0006636.

29. Oxman MN, Levin MJ, Johnson GR, et al. A vaccine to prevent herpes zoster and postherpetic neuralgia in older adults. $N$ Engl $J$ Med. 2005;352(22):2271-2284.

30. Centers for Disease Control and Prevention. What everyone should know about shingles vaccine. CDC; 2016. Available from: https://www.cdc.gov/ vaccines/vpd/shingles/public/index.html. Accessed December 8, 2017.

31. European Medicines Agency. Zostavax European public assessment report. European Medicines Agency (EMEA); 2006. Available from http://www.ema.europa.eu/docs/en_GB/document_library/EPAR_Summary_for_the_public/human/000674/WC500053457.pdf. Accessed December 8, 2017.

32. newswire.ca [homepage on the Internet]. ZOSTAVAX(TM) approved in Canada - The first and only vaccine for the prevention of shingles CISION News Wire; 2008. Available from: http://www.newswire.ca/ news-releases/zostavaxtm-approved-in-canada---the-first-and-onlyvaccine-for-the-prevention-of-shingles-536564411.html. Accessed December 8, 2017.

33. Langan SM, Smeeth L, Margolis DJ, Thomas SL. Herpes zoster vaccine effectiveness against incident herpes zoster and post-herpetic neuralgia in an older US population: a cohort study. PLoS Med. 2013; 10(4): 1001420

34. NHS England. Enhanced service specification Shingles (catch-up) vaccination programme 2014. NHS England gateway reference: 01773. Available from: https://www.england.nhs.uk/wp-content/ uploads/2014/06/shingles-serv-spec.pdf. Accessed August 01, 2017.

35. immunise.health.gov.au [homepage on the Internet]. Immunise Australia Program. Australian Government Department of Health; 2016. Available from: http://immunise.health.gov.au/internet/immunise/ publishing.nsf/Content/IT0213.cnt. Accessed December 8, 2017.

36. news.ontario.ca [homepage on the Internet]. Ontario making shingles vaccine free for seniors. Government of Ontario; 2016. Available from: https://news.ontario.ca/mohltc/en/2016/09/ontario-making-shinglesvaccine-free-for-seniors.html. Accessed December 8, 2017.

37. Diamantopoulos A, Myklebust G, Wigaard E, Amundsen L, Soldal DM, Haugeberg G. The incidence rate of giant cell arteritis in southern Norway is lower than previously reported: A result of temporal variations or a sign of a true shift in incidence rates? Paper presented at: EULAR 2014: Scientific Abstracts, June 13; 2014; Paris, France.

38. Rimseliene G, Vainio K, Gibory M, Salamanca BV, Flem E. Varicellazoster virus susceptibility and primary healthcare consultations in Norway. BMC Infect Dis. 2016;16:254.

39. Franzén P, Sutinen S, von Knorring J. Giant cell arteritis and polymyalgia rheumatica in a region of Finland: an epidemiologic, clinical and pathologic study, 1984-1988. J Rheumatol. 1992;19(2):273-276.

40. Karhunen M, Leino T, Salo H, Davidkin I, Kilpi T, Auranen K. Modelling the impact of varicella vaccination on varicella and zoster. Epidemiol Infect. 2010;138(4):469-481.

41. Mohammad AJ, Nilsson J, Jacobsson LT, Merkel PA, Turesson C. Incidence and mortality rates of biopsy-proven giant cell arteritis in southern Sweden. Ann Rheum Dis. 2015;74(6):993-997.

42. Studahl M, Petzold M, Cassel T. Disease burden of herpes zoster in Sweden - predominance in the elderly and in women - a register based study. BMC Infect Dis. 2013;13:586.
43. Smeeth L, Cook C, Hall AJ. Incidence of diagnosed polymyalgia rheumatica and temporal arteritis in the United Kingdom, 1990-2001. Ann Rheum Dis. 2006;65(8):1093-1098.

44. Brisson M, Edmunds WJ. Epidemiology of varicella-zoster virus in England and Wales. J Med Virol. 2003;70 (Suppl 1):S9-S14.

45. Chandran AK, Udayakumar PD, Crowson CS, Warrington KJ, Matteson EL. The incidence of giant cell arteritis in Olmsted County, Minnesota, over a 60-year period 1950-2009. Scand J Rheumatol. 2015;44(3):215-218.

46. Kawai K, Yawn BP, Wollan P, Harpaz R. Increasing incidence of herpes zoster over a 60-year period from a population-based study. Clin Infect Dis. 2016;63(2):221-226.

47. Gonzalez-Gay MA, Miranda-Filloy JA, Lopez-Diaz MJ, et al. Giant cell arteritis in northwestern Spain: A 25-year epidemiologic study. Medicine (Baltimore). 2007;86(2):61-68.

48. Morant-Talamante N, Diez-Domingo J, Martínez-Úbeda S, PuigBarberá J, Alemán-Sánchez S, Pérez-Breva L. Herpes zoster surveillance using electronic databases in the Valencian Community (Spain). BMC Infect Dis. 2013;13:463.

49. Abdul-Rahman AM, Molteno ACB, Bevin TH. The epidemiology of giant cell arteritis in Otago, New Zealand: a 9-year analysis. $N Z$ Med J. 2011;124(1329):44-52.

50. Reid JS, Ah Wong B. Herpes zoster (shingles) at a large New Zealand general practice: incidence over 5 years. N Z Med J. 2014;127(1407): $56-60$.

51. Bas-Lando M, Breuer GS, Berkun Y, Mates M, Sonnenblick M, Nesher G. The incidence of giant cell arteritis in Jerusalem over a 25-year period: annual and seasonal fluctuations. Clin Exp Rheumatol. 2007;25(1 Suppl 44):S15-S17.

52. Weitzman D, Shavit O, Stein M, Cohen R, Chodick G, Shalev V. A population based study of the epidemiology of herpes zoster and its complications. J Infect. 2013;67(5):463-469.

53. Ramstead CL, Patel AD. Giant cell arteritis in a neuro-ophthalmology clinic in Saskatoon, 1998-2003. Can J Ophthalmol. 2007;42(2): 295-298.

54. Tanuseputro P, Zagorski B, Chan KJ, Kwong JC. Population-based incidence of herpes zoster after introduction of a publicly funded varicella vaccination program. Vaccine. 2011;29(47):8580-8584.

55. Barrier J, Pion P, Massari R, Peltier P, Rojouan J, Grolleau JY. Approche epidemiologique de la maladie de Horton dans le departement de LoireAtlantique 110 cas en 10 ans (1970-1979). [Epidemiologic approach to Horton's disease in the department of Loire-Atlantique. 110 cases in 10 years (1970-1979)]. Rev Med Interne. 1982;3(1):13-20. French.

56. Gonzalez Chiappe S, Sarazin M, Turbelin C, et al. Herpes zoster: Burden of disease in France. Vaccine. 2010;28(50):7933-7938.

57. Catanoso M, Macchioni $\mathrm{P}$, Boiardi L, et al. Incidence, prevalence, and survival of biopsy-proven giant cell arteritis in Northern Italy during a 26-year period. Arthritis Care Res (Hoboken). 2017;69(3):430-438.

58. Gialloreti LE, Merito M, Pezzotti P, et al. Epidemiology and economic burden of herpes zoster and post-herpetic neuralgia in Italy: a retrospective, population-based study. BMC Infect Dis. 2010;10:230.

59. Dunstan E, Lester SL, Rischmueller M, et al. Epidemiology of biopsyproven giant cell arteritis in South Australia. Intern Med J. 2014; 44(1):32-39.

60. Stein AN, Britt H, Harrison C, Conway EL, Cunningham A, Macintyre CR. Herpes zoster burden of illness and health care resource utilisation in the Australian population aged 50 years and older. Vaccine. 2009;27(4): 520-529.

61. Reinhold-Keller E, Herlyn K, Wagner-Bastmeyer R, Gross WL. Stable incidence of primary systemic vasculitides over five years: Results from the German vasculitis register. Arthritis Rheum. 2005;53(1):93-99.

62. Ultsch B, Siedler A, Rieck T, Reinhold T, Krause G, Wichmann O. Herpes zoster in Germany: quantifying the burden of disease. $B M C$ Infect Dis. 2011;11:173

63. Toyama N, Shiraki K; Society of the Miyazaki Prefecture Dermatologists. Epidemiology of herpes zoster and its relationship to varicella in Japan: a 10-year survey of 48,388 herpes zoster cases in Miyazaki prefecture. J Med Virol. 2009;81(12):2053-2058. 


\section{Publish your work in this journal}

Clinical Ophthalmology is an international, peer-reviewed journal covering all subspecialties within ophthalmology. Key topics include: Optometry; Visual science; Pharmacology and drug therapy in eye diseases; Basic Sciences; Primary and Secondary eye care; Patient Safety and Quality of Care Improvements. This journal is indexed on

Submit your manuscript here: http://www.dovepress.com/clinical-ophthalmology-journal
PubMed Central and CAS, and is the official journal of The Society of Clinical Ophthalmology (SCO). The manuscript management system is completely online and includes a very quick and fair peer-review system, which is all easy to use. Visit http://www.dovepress.com/ testimonials.php to read real quotes from published authors. 